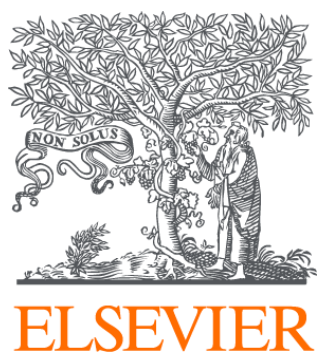

Since January 2020 Elsevier has created a COVID-19 resource centre with free information in English and Mandarin on the novel coronavirus COVID-

19. The COVID-19 resource centre is hosted on Elsevier Connect, the company's public news and information website.

Elsevier hereby grants permission to make all its COVID-19-related research that is available on the COVID-19 resource centre - including this research content - immediately available in PubMed Central and other publicly funded repositories, such as the WHO COVID database with rights for unrestricted research re-use and analyses in any form or by any means with acknowledgement of the original source. These permissions are granted for free by Elsevier for as long as the COVID-19 resource centre remains active. 
Review

\title{
Syncope and COVID-19 disease - A systematic review
}

\author{
Raquel Falcão de Freitas ${ }^{\mathrm{a}, \text {, }}$, Sofia Cardoso Torres ${ }^{\mathrm{b}}$, Francisco Javier Martín-Sánchez ${ }^{\mathrm{c}}$, \\ Adrián Valls Carbó ${ }^{\mathrm{c}}$, Giuseppe Lauria ${ }^{\mathrm{d}}$, José Pedro L. Nunes ${ }^{\mathrm{a}, \mathrm{b}, ",}$

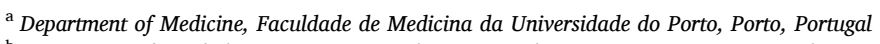 \\ ${ }^{\mathrm{b}}$ Department of Cardiology, Centro Hospitalar Universitário São João, Porto, Portugal \\ ${ }^{\mathrm{c}}$ Departments of Emergency and of Neurology, Hospital Clínico San Carlos, Madrid, Spain \\ d Department of Biomedical and Clinical Sciences "Luigi Sacco", University of Milan, Milan, Italy
}

\section{A R T I C L E I N F O}

\section{Keywords:}

Covid-19

syncope

Arterial hypertension

\begin{abstract}
A B S T R A C T
Background: Syncope is not a common manifestation of COVID-19, but it may occur in this context and it can be the presenting symptom in some cases. Different mechanisms may explain the pathophysiology behind COVID-19 related syncope. In this report, we aimed to examine the current frequency and etiology of syncope in COVID-19. Methods: A systematic review across PubMed, ISI Web of Knowledge and SCOPUS was performed, according to PRISMA guidelines, in order to identify all relevant articles regarding both COVID-19 and syncope.

Results: We identified 136 publications, of which 99 were excluded. The frequency of syncope and pre-syncope across the selected studies was $4.2 \%(604 / 14,437)$. Unexplained syncope was the most common type (87.9\% of the episodes), followed by reflex syncope (7.8\% of the cases). Orthostatic hypotension was responsible for $2.2 \%$ of the cases and syncope of presumable cardiac cause also accounted for $2.2 \%$ of cases. Arterial hypertension was present in $52.0 \%$ of syncope patients. The use of angiotensin receptor blockers or angiotensin converting enzyme inhibitors were not associated with an increased incidence of syncope (chi-square test 1.07, p 0.30), unlike the use of beta-blockers (chi-square test 12.48, $\mathrm{p}<0.01$ ).

Conclusion: Syncope, although not considered a typical symptom of COVID-19, can be associated with it, particularly in early stages. Different causes of syncope were seen in this context. A reevaluation of blood pressure in patients with COVID-19 is suggested, including reassessment of antihypertensive therapy, especially in the case of beta-blockers.
\end{abstract}

\section{Introduction}

The ongoing Coronavirus pandemic has proved to be a challenging setback to the health of the world population ever since its first cases were announced in the city of Wuhan, China, around December 2019. As of the 1st of July 2021, there have been a total of approximately 181 million confirmed cases of COVID-19 (Coronavirus disease 2019) worldwide and 3.9 million deaths, translating to a fatality rate of $2 \%$ (Organization, 2021).

SARS-CoV-2 (severe acute respiratory syndrome coronavirus 2) is a novel betacoronavirus and COVID-19 is the infectious disease caused by this novel virus. Its spike protein (glycoprotein S) determines the specificity of the virus for epithelial cells of the respiratory tract (Santacroce et al., 2020). It is composed of a receptor binding domain that recognizes the ACE-2 (type 2 angiotensin converting enzyme) receptor specifically, allowing the entrance of the virus into its target cells (Wang et al., 2020).
The ACE- 2 receptor can be found on the surface of epithelial cells in the lungs, intestines, kidneys and blood vessels (Santacroce et al., 2020). It is currently known that, although the novel SARS-CoV-2 virus can lead to significant disease in the respiratory system, it can also negatively affect several other vital organ systems. Significant damage, namely, to the cardiovascular, nervous and hematopoietic systems has been outlined and an impact in hemostasis has also been thoroughly discussed as blood hypercoagulability is common among hospitalized COVID-19 patients (Terpos et al., 2020). Regarding the cardiovascular manifestations, heart failure, thromboembolism, myocarditis, arrhythmias, pericarditis and acute coronary syndromes have been described in this context (Shafi et al., 2020; Oates et al., 2020). On the other hand, the most common neurological symptoms reported in COVID-19 patients have been smell and taste disturbances, headache, myalgia, and altered mental status (Favas et al., 2020).

Syncope is largely defined as a transient loss of consciousness due to

\footnotetext{
* Corresponding author at: Faculdade de Medicina da Universidade do Porto, Alameda Prof. Hernâni Monteiro, 4200 Porto, Portugal.

E-mail address: jplnunes@med.up.pt (J.P.L. Nunes).
} 
Table 1

Quality assessment tool for observational cohort and cross-sectional studies. Y - Yes; NR - Not Reported; NA - Not Applicable.

\begin{tabular}{|c|c|c|c|c|c|c|c|c|c|c|c|c|c|}
\hline & $\begin{array}{l}\text { Oates } \\
\text { et al. }\end{array}$ & $\begin{array}{l}\text { Chen } \\
\text { et al. }\end{array}$ & $\begin{array}{l}\text { Canetta } \\
\text { et al. }\end{array}$ & $\begin{array}{l}\text { Radmanesh } \\
\text { et al. }\end{array}$ & $\begin{array}{l}\text { Chachkhiani } \\
\text { et al. }\end{array}$ & $\begin{array}{l}\text { García- } \\
\text { Moncó } \\
\text { et al. }\end{array}$ & $\begin{array}{l}\text { Xiong } \\
\text { et al. }\end{array}$ & $\begin{array}{l}\text { Romero- } \\
\text { Sánchez } \\
\text { et al. }\end{array}$ & $\begin{array}{l}\text { Chuang } \\
\text { et al. }\end{array}$ & $\begin{array}{l}\text { Mizrahi } \\
\text { et al }\end{array}$ & $\begin{array}{l}\text { Martin- } \\
\text { Sanchez } \\
\text { et al. }\end{array}$ & $\begin{array}{l}\text { Travi } \\
\text { et al. }\end{array}$ & $\begin{array}{l}\text { Chou } \\
\text { et al. }\end{array}$ \\
\hline $\begin{array}{l}\text { Was the research } \\
\text { question or } \\
\text { OBJECTIVE in } \\
\text { this paper clearly } \\
\text { stated? }\end{array}$ & $\mathrm{Y}$ & $\mathrm{Y}$ & $\mathrm{Y}$ & $\mathrm{Y}$ & $\mathrm{Y}$ & $\mathrm{Y}$ & $\mathrm{Y}$ & $\mathrm{Y}$ & $\mathrm{Y}$ & $\mathrm{Y}$ & $\mathrm{Y}$ & $\mathrm{Y}$ & $\mathrm{Y}$ \\
\hline $\begin{array}{l}\text { Was the study } \\
\text { population } \\
\text { clearly specified } \\
\text { and defined? }\end{array}$ & $\mathrm{Y}$ & $\mathrm{Y}$ & $\mathrm{Y}$ & $\mathrm{Y}$ & $\mathrm{Y}$ & $\mathrm{Y}$ & $\mathrm{Y}$ & $\mathrm{Y}$ & $\mathrm{Y}$ & $\mathrm{Y}$ & $\mathrm{Y}$ & $\mathrm{Y}$ & $\mathrm{Y}$ \\
\hline $\begin{array}{l}\text { Was the } \\
\text { participation rate } \\
\text { of eligible } \\
\text { persons at least } \\
50 \% ?\end{array}$ & $\mathrm{Y}$ & $\mathrm{Y}$ & $\mathrm{Y}$ & $\mathrm{Y}$ & $\mathrm{Y}$ & $\mathrm{Y}$ & $\mathrm{Y}$ & $\mathrm{Y}$ & $\mathrm{Y}$ & $\mathrm{Y}$ & $\mathrm{Y}$ & $\mathrm{Y}$ & $\mathrm{Y}$ \\
\hline $\begin{array}{l}\text { Were all the } \\
\text { subjects selected } \\
\text { or recruited from } \\
\text { the same or } \\
\text { similar } \\
\text { populations } \\
\text { (including the } \\
\text { same time } \\
\text { period)? Were } \\
\text { inclusion and } \\
\text { exclusion criteria } \\
\text { for being in the } \\
\text { study } \\
\text { prespecified and } \\
\text { applied } \\
\text { uniformly to all } \\
\text { participants? }\end{array}$ & $\mathrm{Y}$ & $\mathrm{Y}$ & $\mathrm{Y}$ & $\mathrm{Y}$ & $\mathrm{Y}$ & $\mathrm{Y}$ & $\mathrm{Y}$ & $\mathrm{Y}$ & $\mathrm{Y}$ & $\mathrm{Y}$ & $\mathrm{Y}$ & $\mathrm{Y}$ & $\mathrm{Y}$ \\
\hline $\begin{array}{l}\text { Was a sample size } \\
\text { justification, } \\
\text { power } \\
\text { description, or } \\
\text { variance and } \\
\text { effect estimates } \\
\text { provided? }\end{array}$ & NR & NR & NR & NR & NR & NR & NR & NR & NR & NR & NR & NR & NR \\
\hline $\begin{array}{l}\text { For the analyses in } \\
\text { this paper, were } \\
\text { the exposure(s) } \\
\text { of interest } \\
\text { measured prior to } \\
\text { the outcome(s) } \\
\text { being measured? }\end{array}$ & NA & NA & NA & NA & NA & NA & NA & NA & NA & NA & NA & NA & NA \\
\hline $\begin{array}{l}\text { Was the timeframe } \\
\text { sufficient so that } \\
\text { one could } \\
\text { reasonably } \\
\text { expect to see an } \\
\text { association } \\
\text { between } \\
\text { exposure and } \\
\text { outcome if it } \\
\text { existed? }\end{array}$ & $\mathrm{Y}$ & $\mathrm{Y}$ & $\mathrm{Y}$ & $\mathrm{Y}$ & $\mathrm{Y}$ & $\mathrm{Y}$ & $\mathrm{Y}$ & $\mathrm{Y}$ & $\mathrm{Y}$ & $\mathrm{Y}$ & $\mathrm{Y}$ & $\mathrm{Y}$ & $\mathrm{Y}$ \\
\hline $\begin{array}{l}\text { For exposures that } \\
\text { can vary in } \\
\text { amount or level, } \\
\text { did the study } \\
\text { examine different } \\
\text { levels of the } \\
\text { exposure as } \\
\text { related to the } \\
\text { outcome (e.g., } \\
\text { categories of } \\
\text { exposure, or } \\
\text { exposure } \\
\text { measured as } \\
\text { continuous } \\
\text { variable)? }\end{array}$ & NA & NA & NA & NA & NA & NA & NA & NA & NA & NA & NA & NA & NA \\
\hline $\begin{array}{l}\text { Were the exposure } \\
\text { measures }\end{array}$ & $\mathrm{Y}$ & $\mathrm{Y}$ & $\mathrm{Y}$ & $\mathrm{Y}$ & $\mathrm{Y}$ & $\mathrm{Y}$ & $\mathrm{Y}$ & $\mathrm{Y}$ & $\mathrm{Y}$ & $\mathrm{Y}$ & $\mathrm{Y}$ & $\mathrm{Y}$ & $\mathrm{Y}$ \\
\hline
\end{tabular}


Table 1 (continued)

\begin{tabular}{|c|c|c|c|c|c|c|c|c|c|c|c|c|c|}
\hline & $\begin{array}{l}\text { Oates } \\
\text { et al. }\end{array}$ & $\begin{array}{l}\text { Chen } \\
\text { et al. }\end{array}$ & $\begin{array}{l}\text { Canetta } \\
\text { et al. }\end{array}$ & $\begin{array}{l}\text { Radmanesh } \\
\text { et al. }\end{array}$ & $\begin{array}{l}\text { Chachkhiani } \\
\text { et al. }\end{array}$ & $\begin{array}{l}\text { García- } \\
\text { Moncó } \\
\text { et al. }\end{array}$ & $\begin{array}{l}\text { Xiong } \\
\text { et al. }\end{array}$ & $\begin{array}{l}\text { Romero- } \\
\text { Sánchez } \\
\text { et al. }\end{array}$ & $\begin{array}{l}\text { Chuang } \\
\text { et al. }\end{array}$ & $\begin{array}{l}\text { Mizrahi } \\
\text { et al }\end{array}$ & $\begin{array}{l}\text { Martin- } \\
\text { Sanchez } \\
\text { et al. }\end{array}$ & $\begin{array}{l}\text { Travi } \\
\text { et al. }\end{array}$ & $\begin{array}{l}\text { Chou } \\
\text { et al. }\end{array}$ \\
\hline \multicolumn{14}{|l|}{$\begin{array}{l}\text { (independent } \\
\text { variables) clearly } \\
\text { defined, valid, } \\
\text { reliable, and } \\
\text { implemented } \\
\text { consistently } \\
\text { across all study } \\
\text { participants? }\end{array}$} \\
\hline $\begin{array}{l}\text { Was the exposure } \\
\text { (s) assessed more } \\
\text { than once over } \\
\text { time? }\end{array}$ & NR & NR & NR & NR & NR & NR & NR & NR & NR & $\mathrm{Y}$ & $\mathrm{Y}$ & NR & NR \\
\hline $\begin{array}{l}\text { Were the outcome } \\
\text { measures } \\
\text { (dependent } \\
\text { variables) clearly } \\
\text { defined, valid, } \\
\text { reliable, and } \\
\text { implemented } \\
\text { consistently } \\
\text { across all study } \\
\text { participants? }\end{array}$ & $\mathrm{Y}$ & $\mathrm{Y}$ & $\mathrm{Y}$ & $\mathrm{Y}$ & $\mathrm{Y}$ & $\mathrm{Y}$ & $\mathrm{Y}$ & $\mathrm{Y}$ & $\mathrm{Y}$ & $\mathrm{Y}$ & $\mathrm{Y}$ & $\mathrm{Y}$ & $\mathrm{Y}$ \\
\hline $\begin{array}{l}\text { Were the outcome } \\
\text { assessors blinded } \\
\text { to the exposure } \\
\text { status of } \\
\text { participants? }\end{array}$ & NA & NA & NA & NA & NA & NA & NA & NA & NA & NA & NA & NA & NA \\
\hline $\begin{array}{l}\text { Was loss to follow- } \\
\text { up after baseline } \\
20 \% \text { or less? }\end{array}$ & NR & NR & NR & NR & NR & NR & NR & NR & NR & NR & NR & NR & NR \\
\hline $\begin{array}{l}\text { Were key potential } \\
\text { confounding } \\
\text { variables } \\
\text { measured and } \\
\text { adjusted } \\
\text { statistically for } \\
\text { their impact on } \\
\text { the relationship } \\
\text { between } \\
\text { exposure(s) and } \\
\text { outcome(s)? }\end{array}$ & NR & NR & NR & NR & $\mathrm{Y}$ & NR & NR & NR & NR & $\mathrm{Y}$ & $\mathrm{Y}$ & $\mathrm{Y}$ & $\mathrm{Y}$ \\
\hline Quality rating & Good & Fair & Good & Good & Good & Fair & Fair & Fair & Fair & Good & Good & Good & Good \\
\hline
\end{tabular}

cerebral hypoperfusion (Cardiology ESo, 2018). It is characterized by a rapid onset, short duration and spontaneous, complete recovery (Cardiology ESo, 2018). Presyncope, on the other hand, is the state that resembles the prodrome of syncope (with all its signs and symptoms such as pallor, sweating, nausea, palpitations) without being followed by a loss of consciousness (Cardiology ESo, 2018).

In the light of a severe systemic disease, non-traumatic transient loss of consciousness can have distinct etiologies, varying from the benign reflex syncope and syncope due to orthostatic hypotension to the increasingly serious cardiac syncope (Brignole et al., 2018). Apart from unexplained syncope, these three main groups stem from different mechanisms and, therefore, may require specialized treatment. Consequently, an accurate diagnosis becomes imperative.

Recently, some case reports and case-series have emerged reporting syncope as a possible symptom of COVID-19, whether it had developed at the onset or during the course of the disease (Oates et al., 2020). It is important to mention that some of these reports outline its occurrence days before the main respiratory symptoms, or even as an isolated phenomenon (Ebrille et al., 2020). If a valid relationship between COVID-19 and syncope is established, a number of patients could be isolated in a timely manner, minimizing the contagious phase.

In the present report, we aimed to systematically review the recent published literature that describes syncope or presyncope as a symptom of COVID-19, having it been observed in the days before or after the diagnosis. We aimed to calculate its frequency and divide it into each different type of syncope observed.

As a secondary aim of the review, the investigation of the relationship between syncope and use of angiotensin receptor inhibitor drugs (ACEi), angiotensin receptor blockers (ARBs) and/or beta-blockers in the context of COVID-19 was carried out. This seemed to be important to investigate since arterial hypertension is a common comorbidity among COVID-19 patients (Tadic et al., 2020), and the use of standard antihypertensive agents could influence the incidence of this symptom.

\section{Methods}

\subsection{Eligibility criteria}

Regarding our population of interest, we were in the search for studies that simultaneously described COVID-19 and syncope or presyncope presented as a possible symptom of the acute infection or occuring in a post-acute COVID-19 setting. Articles were excluded if they described falls in the context of COVID-19 that were not stated to be of syncopal origin; episodes of syncope not temporally related with SARS-CoV-2 infection (for example, occurring throughout the year prior to the infection) and episodes of syncope with another possible underlying cause mentioned in the study as relevant apart from COVID-19. We included case-series, case-reports, cross-sectional studies with prospective data collection, retrospective analyses and letters published in 2020 or 2021 for which it was possible to extract an exact number of patients 
Table 2

Quality assessment tool for case-series studies. Y - Yes; NR - Not reported; NA Not applicable.

\begin{tabular}{|c|c|c|c|c|c|}
\hline & $\begin{array}{l}\text { Ebrille } \\
\text { et al. }\end{array}$ & $\begin{array}{l}\text { Birlutiu } \\
\text { et al. }\end{array}$ & $\begin{array}{l}\text { Argenziano } \\
\text { et al. }\end{array}$ & $\begin{array}{l}\text { Espinoza } \\
\text { et al. }\end{array}$ & $\begin{array}{l}\text { Gonfiotti } \\
\text { et al. }\end{array}$ \\
\hline $\begin{array}{l}\text { Was the study } \\
\text { question or } \\
\text { objective } \\
\text { clearly stated? }\end{array}$ & $\mathrm{Y}$ & $\mathrm{Y}$ & $\mathrm{Y}$ & $\mathrm{Y}$ & $\mathrm{Y}$ \\
\hline $\begin{array}{l}\text { Was the study } \\
\text { population } \\
\text { clearly and } \\
\text { fully } \\
\text { described, } \\
\text { including a } \\
\text { case } \\
\text { definition? }\end{array}$ & $\mathrm{Y}$ & $\mathrm{Y}$ & $\mathrm{Y}$ & $\mathrm{Y}$ & $\mathrm{Y}$ \\
\hline $\begin{array}{c}\text { Were the cases } \\
\text { consecutive? }\end{array}$ & NR & NR & $\mathrm{Y}$ & NR & NR \\
\hline $\begin{array}{l}\text { Were the } \\
\text { subjects } \\
\text { comparable? }\end{array}$ & $\mathrm{Y}$ & $\mathrm{Y}$ & $\mathrm{Y}$ & $\mathrm{Y}$ & $\mathrm{Y}$ \\
\hline $\begin{array}{l}\text { Was the } \\
\text { intervention } \\
\text { clearly } \\
\text { described? }\end{array}$ & $\mathrm{Y}$ & $\mathrm{Y}$ & $\mathrm{Y}$ & $\mathrm{Y}$ & $\mathrm{Y}$ \\
\hline $\begin{array}{l}\text { Were the } \\
\text { outcome } \\
\text { measures } \\
\text { clearly } \\
\text { defined, valid, } \\
\text { reliable, and } \\
\text { implemented } \\
\text { consistently } \\
\text { across all study } \\
\text { participants? }\end{array}$ & $\mathrm{Y}$ & $\mathrm{Y}$ & $\mathrm{Y}$ & $\mathrm{Y}$ & $\mathrm{Y}$ \\
\hline $\begin{array}{l}\text { Was the length of } \\
\text { follow-up } \\
\text { adequate? }\end{array}$ & NR & $\mathrm{Y}$ & $\mathrm{Y}$ & NR & $\mathrm{Y}$ \\
\hline $\begin{array}{l}\text { Were the } \\
\text { statistical } \\
\text { methods well- } \\
\text { described? }\end{array}$ & NA & NA & $\mathrm{Y}$ & NA & NA \\
\hline $\begin{array}{l}\text { Were the results } \\
\text { well- } \\
\text { described? }\end{array}$ & $\mathrm{Y}$ & $\mathrm{Y}$ & $\mathrm{Y}$ & $\mathrm{Y}$ & $\mathrm{Y}$ \\
\hline Quality Rating & Fair & Good & Good & Fair & Good \\
\hline
\end{tabular}

with COVID-19 exhibiting syncope/presyncope.

We did not restrict articles to witnessed syncope nor exclude articles that did not describe the specific comorbidities, clinical characteristics or evolution exhibited by the pre/syncope cohort. This was because our primary outcome measure was to quantify the number of COVID-19 related pre/syncopal episodes published in the literature thus far.

We considered articles written in English, Spanish, French, Italian, or Portuguese. Articles written in German, Hungarian or Mandarin were excluded (since the authors are not familiar with these languages).

\subsection{Search strategy}

A comprehensive literature search was carried out with the purpose of identifying all reported articles relating syncope to COVID-19, according to the guidelines for Preferred Reporting Items for Systematic Reviews and Meta-Analyses (Page et al., 2021). This search was conducted on the databases Medline (PUBMED), ISI Web of Knowledge and SCOPUS.

The search query, which took place on the 9th of March 2021, included the following MeSH terms and keywords: "(COVID-19" OR "COVID 19" OR "SARS-COV-2" OR "coronavirus" OR "2019 novel coronavirus") AND ("syncope" OR "presyncope" OR "syncopal"). Additionally, we scanned the list of references from the included studies in this analysis and of systematic reviews pertaining to neurological symptoms in the context of COVID-19.

\subsection{Selection process}

Two investigators independently assessed whether the studies addressed the topic in question and if all the inclusion/exclusion criteria were met. Initially, this was done according to the "screening phase", where only the title and the abstract were analyzed. After this process, 52 articles were considered eligible. This was followed by the "inclusion phase", where the integral text was fully evaluated. Any doubtful situation was solved by consensus between the authors, after which, concerning study eligibility, $100 \%$ agreement between authors was seen in each step of the study assessment.

\subsection{Data collection process and data items}

From the selected articles, two authors worked independently to retrieve the following data: location, number of patients (with and without pre/syncope), age, sex and ethnicity when available, comorbidities (from patients with and without pre/syncope), chronic medications the patients were on regarding treatment of arterial hypertension and the description of the clinical course, including relevant laboratory findings and any auxiliary exams performed, such as computerized tomography scans and cardiac magnetic resonances. Any doubtful situation was solved by consensus between the authors.

\subsection{Study quality assessment}

Quality of the observational cohorts and cross-sectional studies and case-series was evaluated using the National Heart, Lung and Blood Institute study quality assessment tools (National Heart LaBI, 2021) and is presented in Tables 1 and 2. Any disagreements between the two main reviewers were discussed with a third evaluator.

\subsection{Outcome measures}

The primary outcome measures assessed were the occurrence of syncope or presyncope either in the days prior or subsequent to a COVID-19 diagnosis and its relative frequency, divided into each type of syncope experienced.

We also assessed the association between the usage of ARBs or ACEi and beta blockers with the occurence of syncope as well as the association of syncope with mortality.

\subsection{Effect measures}

Concerning these latter data, a chi-square test was used, with a level of significance of 0.05 . Statistical analysis was done using Stata, version 17.0, StataCorp, Texas, USA.

\section{Results}

\subsection{Study selection}

With the use of our keywords, we obtained 51 results from Medline (PUBMED), 28 from ISI Web of Knowledge, 50 from SCOPUS and 7 from scanning the references of the selected articles and adequate systematic reviews (Fig. 1) - with a total number of 37 articles selected for the purpose of the present study (Fig. 1). The complete set of selected studies is presented in Table 3. SARS-CoV-2 infection was diagnosed by realtime reverse transcriptase polymerase chain reaction (RT-PCR) or a chest X-ray or CT scan showing the characteristic bilateral interstitial pneumonia of COVID-19 in all cases, except in the report by RomeroSánchez et al., in which a minority of patients were diagnosed by means of serological testing (Romero-Sánchez et al., 2020).

The excluded full-text articles are presented in Table 4, with the 


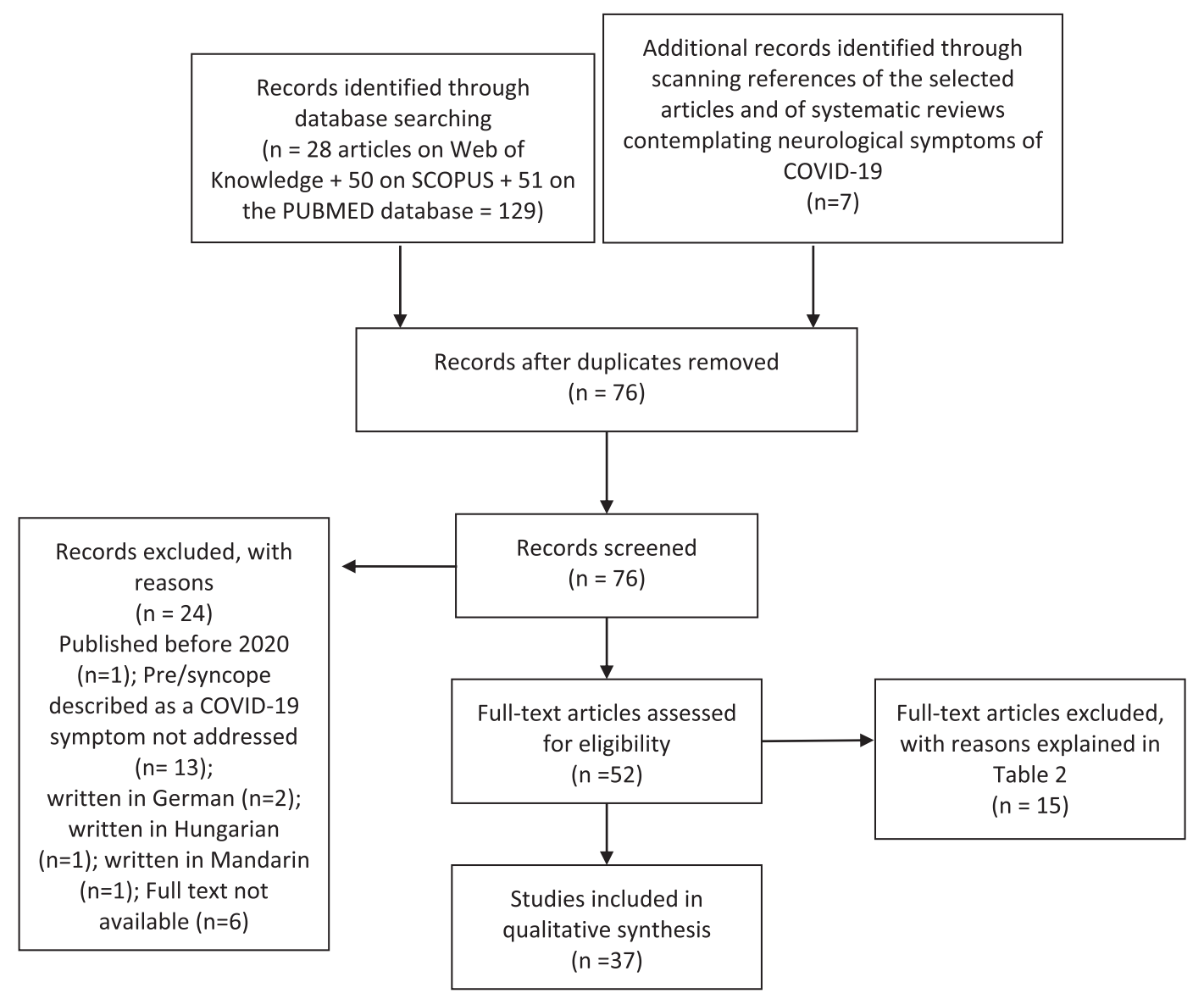

Fig. 1. Flowchart showing literature search method. $\mathrm{n}=$ number of articles.

corresponding reasons.

\subsection{Study characteristics}

Of the 37 included articles, 18 were case reports (Tapé et al., 2013, Sang et al., 2020, Pasquetto et al., 2020, Luetkens et al., 2020, Logmin et al., 2020, Chang et al., 2020, Singhania et al., 2020, Huang et al., 2020, Omotosho et al., 2021, Khan et al., 2020, Chalela et al., 2020, Pérez et al., 2020, Chibane et al., 2020, Pendower et al., 2020, Aoi et al., 2020, Doodnauth et al., 2021, Kanjwal et al., 2020, Miglis et al., 2020), 10 were retrospective analyses (Oates et al., 2020, Romero-Sánchez et al., 2020, Chachkhiani et al., 2020, Xiong et al., 2020, Radmanesh et al., 2020, Canetta et al., 2020, Chuang et al., 2021, Mizrahi et al., 2020, Martín-Sánchez et al., 2020, Travi et al., 2020), 5 were case-series (Ebrille et al., 2020, Birlutiu et al., 2020, Argenziano et al., 2020, Espinoza et al., 2021, Gonfiotti et al., 2020) and 2 were prospective studies (García-Moncó et al., 2020, Chen et al., 2020). One was a letter (Lam et al., 2020). The study by Chou et al. (2021), included both retrospective and prospective data collection. Given the nature of this topic, every article was published in either 2020 or 2021 . The United States of America contributed with most of the studies, with a total of 18 articles. 15 articles were conducted in Europe, 1 was from Canada, 1 from Australia and 1 from China. The study by Chou et al. (2021) represented 13 different countries and 4 continents.

The sample size included in the studies varied from 1 to 5427 patients. The mean age ranged from 26 to 84 years of age. Considering the studies in which it was possible to extract the sex of COVID-19 patients who experienced syncope, we found that $61.2 \%$ were male. The overall male percentage (including COVID-19 patients with syncope and without syncope) was $55.9 \%$. Ethnicity data, when available, are presented in Table 3.
Information regarding number of participants, mean age, sex and usage of ARBs/ACEi as well as usage of beta-blockers in the syncope versus non-syncope cohort was available for 5 studies and is presented in Table 5.

\subsection{Synthesis of results}

There were 604 cases of syncope and pre-syncope related to COVID19 out of a total of 14,438 patients contemplated in this review, comprising an overall frequency of $4.2 \%$.

The majority of studies, 16, described syncopal episodes of unexplained etiology (Romero-Sánchez et al., 2020, Pérez et al., 2020, Chachkhiani et al., 2020, Xiong et al., 2020, Radmanesh et al., 2020, Chuang et al., 2021, Pérez et al., 2020; Mizrahi et al., 2020, MartínSánchez et al., 2020, Travi et al., 2020, Argenziano et al., 2020, Gonfiotti et al., 2020, García-Moncó et al., 2020, Chen et al., 2020, Lam et al., 2020, Chou et al., 2021). 10 case reports alluded to possible cardiac etiology for syncope (Sang et al., 2020, Pasquetto et al., 2020, Luetkens et al., 2020, Chang et al., 2020, Khan et al., 2020, Chalela et al., 2020, Chibane et al., 2020, Pendower et al., 2020, Aoi et al., 2020, Doodnauth et al., 2021) as well as 1 case series (Espinoza et al., 2021), while another 6 studies attributed the cause of syncope to orthostatic hypotension (Ebrille et al., 2020, Tapé et al., 2013, Logmin et al., 2020, Singhania et al., 2020, Huang et al., 2020, Omotosho et al., 2021). In turn, reflex syncope was highlighted in only 3 of the studies (Ebrille et al., 2020, Canetta et al., 2020, Birlutiu et al., 2020). The retrospective study by Oates et al. (2020) contemplated all of the different types of syncope.

Two studies (Kanjwal et al., 2020, Miglis et al., 2020) described the occurrence of syncope in COVID-19 survivors, 3 to 4 weeks after diagnosis, in a post-acute COVID-19 phase. This raises the possibility of 
Table 3

Summary of included articles. Pts - patients; ARBs - angiotensin receptor blockers; PPM - permanent pacemaker implantation; ECG - electrocardiogram; ICD implantable cardioverter-defibrillator; AV - atrioventricular; ACE-I - angiotensin-converting-enzyme inhibitors; CMR - cardiac magnetic resonance; CSF - cerebrospinal fluid; CT -computed tomography; MRI - magnetic resonance imaging; RT-PCR - real time polymerase chain reaction; CRP - C-Reactive Protein, NT-proBNP - N-terminal type B natriuretic peptide; POTS - Postural Orthostatic Tachycardia Syndrome; BP - blood pressure. For references see text.

\begin{tabular}{|c|c|c|c|c|c|c|}
\hline Source & Study type & Patients (n) & Patient characteristics & Comorbidities & Main findings & Syncope type \\
\hline $\begin{array}{l}\text { Oates et al. } \\
\text { (U.S.A.) }\end{array}$ & $\begin{array}{l}\text { Retrospective } \\
\text { study }\end{array}$ & $\begin{array}{l}77 \text { (Syncope cohort: } \\
37 \text { pts. ( } 32 \text { with } \\
\text { syncope and } 5 \text { with } \\
\text { presyncope); control } \\
\text { group: } 40 \text { pts. } \\
\text { without syncope/ } \\
\text { presyncope) }\end{array}$ & $\begin{array}{l}\text { Syncope cohort: } \\
\text { Median age: } 69 \\
51 \% \text { males } \\
24 \% \text { Caucasian }\end{array}$ & $\begin{array}{l}\text { Syncope cohort: Arterial } \\
\text { Hypertension (68\%); Obesity } \\
\text { (42\%); Diabetes mellitus } \\
\text { (32\%); Coronary Artery } \\
\text { Disease (27\%); Chronic } \\
\text { Kidney Disease (11\%); Atrial } \\
\text { Fibrillation (8\%) }\end{array}$ & $\begin{array}{l}\text { Incidence of syncope/ } \\
\text { presyncope was } 3.7 \% \text {; Syncope } \\
\text { cohort: greater use of ARBs } \\
\text { ( } \mathrm{p}=0.03 \text { ); Systolic blood } \\
\text { pressure lower in the syncope } \\
\text { cohort ( } \mathrm{p}=0.01 \text { ); Pulse rate } \\
\text { lower in syncope cohort } \\
\text { ( } \mathrm{p}<0.0001 \text { ); Compared with } \\
\text { the "control" group, there were } \\
\text { no significant differences in } \\
\text { both admission and peak blood } \\
\text { levels of D-dimer, troponin-I, } \\
\text { and CRP in the syncope cohort; } \\
\text { Syncope cohort required less } \\
\text { intensive care unit admissions \& } \\
\text { had lower need for mechanical } \\
\text { ventilation }\end{array}$ & $\begin{array}{l}-59.4 \% \\
\text { Unexplained } \\
-15.6 \% \\
\text { Neurocardiogenic/ } \\
\text { Reflex } \\
-12.5 \% \\
\text { Hypotensive } \\
-3.1 \% \\
\text { Cardiopulmonary }\end{array}$ \\
\hline $\begin{array}{l}\text { Chen et al. } \\
\text { (U.S.A) }\end{array}$ & $\begin{array}{l}\text { Prospective } \\
\text { study }\end{array}$ & $\begin{array}{l}\text { 102; (syncope cohort: } \\
24 \text { pts. with syncope, } \\
\text { near syncope or } \\
\text { nonmechanical fall) }\end{array}$ & $\begin{array}{l}\text { Syncope cohort: } \\
\text { Mean age: } 61\end{array}$ & $\begin{array}{l}\text { Syncope cohort: } \\
\text { Cardiovascular disease } \\
\text { history in } 29 \% \text {. }\end{array}$ & $\begin{array}{l}\text { More pts. from the syncope } \\
\text { cohort required oxygen, had } \\
\text { gastrointestinal symptoms and } \\
\text { elevated troponin levels } \\
\text { compared to the rest of the pts. } \\
(p>0.05) \text {. }\end{array}$ & Unexplained \\
\hline $\begin{array}{l}\text { Ebrille et al. } \\
\text { (Italy) }\end{array}$ & Case-series & $\begin{array}{l}5 \text {; ( } 2 \text { pts. with } \\
\text { syncope and } 3 \text { with } \\
\text { presyncope) }\end{array}$ & $\begin{array}{l}\text { Patient 1: } 71 \text { year old } \\
\text { male } \\
\text { Patient 2: } 65 \text { year old } \\
\text { female } \\
\text { Patient 3: } 79 \text { year old } \\
\text { male } \\
\text { Patient 4: } 75 \text { year old } \\
\text { male } \\
\text { Patient 5: } 75 \text { year old } \\
\text { male }\end{array}$ & $\begin{array}{l}\text { Patient 1: Arterial } \\
\text { Hypertension, Coronary } \\
\text { Artery Disease and PPM; } \\
\text { Patient 2: Mitral Valve } \\
\text { stenosis, PPM for AV block, } \\
\text { Atrial Fibrillation; Patient 3: } \\
\text { Arterial Hypertension, } \\
\text { Diabetes Mellitus, Transient } \\
\text { Ischemic Attack, 3rd degree } \\
\text { AV block; Patient 4: Chagas } \\
\text { disease, PPM due to AV } \\
\text { block, ICD because of } \\
\text { ventricular tachycardia; } \\
\text { Patient 5: Dilated } \\
\text { Cardiomyopathy, PPM. }\end{array}$ & $\begin{array}{l}\text { All patients had an episode of } \\
\text { syncope as the only initial } \\
\text { symptom of COVID- } 19 \\
\text { infection; } 4 / 5 \text { patients were on } \\
\text { ACE-I chronic therapy; Syncope } \\
\text { due to arrhythmia, structural } \\
\text { cardiac disease or pulmonary } \\
\text { embolism was excluded. }\end{array}$ & $\begin{array}{l}\text { Reflex } \\
\text { Autonomic } \\
\text { Dysfunction, either } \\
\text { primary or } \\
\text { secondary }\end{array}$ \\
\hline $\begin{array}{l}\text { Chang et al. } \\
\text { (U.S.A) }\end{array}$ & Case report & 1 & $\begin{array}{l}49 \text { year old } \\
\text { Male }\end{array}$ & $\begin{array}{l}\text { No significant medical } \\
\text { history. }\end{array}$ & $\begin{array}{l}\text { Syncope and fever; ECG with } \\
\text { Brugada pattern, uncovered } \\
\text { during fever; Brugada } \\
\text { Syndrome diagnosis. }\end{array}$ & $\begin{array}{l}\text { Presumable cardiac } \\
\text { cause }\end{array}$ \\
\hline $\begin{array}{l}\text { Pasquetto } \\
\text { et al. } \\
\text { (Italy) }\end{array}$ & Case report & 1 & $\begin{array}{l}52 \text { year old } \\
\text { Male }\end{array}$ & - & $\begin{array}{l}\text { Dyspnea and fever; } 2 \text { episodes of } \\
\text { syncope during high fever; CRP } \\
\text { was } 160.7 \mathrm{mg} / \mathrm{L} \text { and the } \\
\text { troponin level was normal; The } \\
\text { ECG presented a "coved-type" } \\
\text { aspect in leads V1 and V2 and a } \\
\text { first-degree AV block; Brugada } \\
\text { Syndrome diagnosis. }\end{array}$ & $\begin{array}{l}\text { Presumable cardiac } \\
\text { cause }\end{array}$ \\
\hline $\begin{array}{l}\text { Luetkens } \\
\text { et al. } \\
\text { (Germany) }\end{array}$ & Case report & 1 & $\begin{array}{l}79 \text { year old } \\
\text { Male }\end{array}$ & Asthma & $\begin{array}{l}\text { Elevated CRP, troponin T and } \\
\text { NT-proBNP; CMR showed } \\
\text { diffuse interstitial myocardial } \\
\text { edema with mild systolic } \\
\text { dysfunction and mild } \\
\text { pericardial effusion; COVID-19 } \\
\text { associated myocarditis } \\
\text { diagnosis. }\end{array}$ & $\begin{array}{l}\text { Presumable cardiac } \\
\text { cause }\end{array}$ \\
\hline $\begin{array}{l}\text { Logmin et al. } \\
\text { (Germany) }\end{array}$ & Case report & 1 & $\begin{array}{l}70 \text { year old Female } \\
\text { History of syncopes } \\
\text { over the years but not } \\
\text { lately }\end{array}$ & $\begin{array}{l}\text { Psoriatic Arthritis; } \\
\text { Neuropathic Pain; } \\
\text { Paroxysmal Atrial } \\
\text { Fibrillation. }\end{array}$ & $\begin{array}{l}3 \text { episodes of syncope, one of } \\
\text { which convulsive; Respiratory } \\
\text { symptoms emerged later; } \\
\text { Normal long-term ECG, blood } \\
\text { pressure monitoring and } \\
\text { Schellong test; Initially, levels of } \\
\text { D-dimer and LDH were normal, } \\
\text { but both increased in the } \\
\text { following days; Brain MRI } \\
\text { without acute alterations (signs } \\
\text { of minimal previous ischemic } \\
\text { events); Normal } \\
\text { Electroencephalogram and CSF }\end{array}$ & $\begin{array}{l}\text { Autonomic } \\
\text { dysfunction }\end{array}$ \\
\hline
\end{tabular}


Table 3 (continued)

\begin{tabular}{|c|c|c|c|c|c|c|}
\hline Source & Study type & Patients (n) & Patient characteristics & Comorbidities & Main findings & Syncope type \\
\hline $\begin{array}{l}\text { Tapé et al. } \\
\text { (U.S.A) }\end{array}$ & Case report & 1 & $\begin{array}{l}79 \text { year old } \\
\text { Female }\end{array}$ & $\begin{array}{l}\text { Coronary Artery Disease } \\
\text { with multiple stents; Arterial } \\
\text { Hypertension; Congestive } \\
\text { Heart Failure. }\end{array}$ & $\begin{array}{l}\text { analysis; Pathological } \\
\text { Sympathetic Skin Response. } \\
\text { Syncopal episode, myalgia, } \\
\text { cough and fever; Initially } \\
\text { admitted in the Emergency } \\
\text { Department for a syncopal } \\
\text { workup; BP of } 116 / 62 \mathrm{mmHg} \\
\text { sitting \& } 85 / 50 \mathrm{mmHg} \\
\text { standing; Normal ECG and } \\
\text { telemetry monitoring; Fever } \\
\text { later prompted SARS-CoV-2 } \\
\text { testing; Developed respiratory } \\
\text { failure later }\end{array}$ & $\begin{array}{l}\text { Orthostatic } \\
\text { hypotension }\end{array}$ \\
\hline $\begin{array}{l}\text { Canetta et al. } \\
\text { (Italy) }\end{array}$ & $\begin{array}{l}\text { Retrospective } \\
\text { analysis }\end{array}$ & $\begin{array}{l}103 \\
\text { ( } 35 \text { pts. with syncope } \\
\text { and } 68 \text { pts. without) }\end{array}$ & $\begin{array}{l}\text { Mean age } \\
\text { With syncope: } 74 \\
\text { Without syncope: } 72 \\
69 \% \text { of the pts. with } \\
\text { syncope were male }\end{array}$ & $\begin{array}{l}\text { Syncope cohort: Arterial } \\
\text { Hypertension (45.7\%); } \\
\text { Dyslipidemia (17\%); Renal } \\
\text { insufficiency (20\%); } \\
\text { Hypothyroidism (5.7\%); } \\
\text { Dementia (11.4\%); Cancer } \\
(11.4 \%) \text {; Atrial Fibrillation } \\
(5.7 \%) \text {. }\end{array}$ & $\begin{array}{l}\text { Hypocapnic Hypoxemia in most } \\
\text { patients; Mean heart rate was } \\
\text { significantly lower in pts. who } \\
\text { experienced syncope; Patients } \\
\text { reporting syncope had a normal } \\
\text { cardiac assessment }\end{array}$ & Reflex \\
\hline $\begin{array}{l}\text { Singhania } \\
\text { et al. } \\
\text { (U.S.A) }\end{array}$ & Case report & 1 & $\begin{array}{l}71 \text { year old } \\
\text { Female }\end{array}$ & Arterial Hypertension & $\begin{array}{l}\text { Syncope and later altered } \\
\text { mental status as the only } \\
\text { complaints that ultimately led } \\
\text { to COVID-19 diagnosis; } \\
\text { Tachycardia, normal ECG. }\end{array}$ & $\begin{array}{l}\text { Orthostatic } \\
\text { hypotension }\end{array}$ \\
\hline $\begin{array}{l}\text { Sang et al. } \\
\text { (U.S.A) }\end{array}$ & Case Report & 1 & $\begin{array}{l}62 \text { year old } \\
\text { Male }\end{array}$ & $\begin{array}{l}\text { Arterial Hypertension } \\
\text { Dyslipidemia }\end{array}$ & $\begin{array}{l}\text { Patient with syncope, } \\
\text { ventricular fibrillation and } \\
\text { shock secondary to a massive } \\
\text { pulmonary embolism in the } \\
\text { setting of SARS-CoV-2 infection; } \\
\text { Elevated troponin I, BNP, and D- } \\
\text { dimer }\end{array}$ & Cardiopulmonary \\
\hline $\begin{array}{l}\text { Birlutiu et al. } \\
\text { (Romania) }\end{array}$ & Case-series & 4 & $\begin{array}{l}\text { Patient 1: } 67 \text { year old } \\
\text { Caucasian male; } \\
\text { Patient 2: } 65 \text { year old } \\
\text { Caucasian female; } \\
\text { Patient 3: } 61 \text { year old } \\
\text { Caucasian male; } \\
\text { Patient 4: } 48 \text { year old } \\
\text { Caucasian female }\end{array}$ & $\begin{array}{l}\text { Patient 1: Arterial } \\
\text { Hypertension, Stroke, } \\
\text { Diabetes mellitus; Patient 2: } \\
\text { Diabetes Mellitus, arterial } \\
\text { hypertension, 3rd degree AV } \\
\text { block with pacemaker; } \\
\text { Patient 3: -; Patient 4: -. }\end{array}$ & $\begin{array}{l}\text { All } 4 \text { patients presented with } \\
\text { syncope after micturition; } 2 \text { of } \\
\text { them had associated intense, } \\
\text { persistent headaches either } \\
\text { preceding or post syncope and } 1 \\
\text { of them had diffuse abdominal } \\
\text { pain and nausea as warning } \\
\text { signs; One patient had an } \\
\text { elevated D-dimer and } 3 \text { of them } \\
\text { had an elevated CRP; Time of } \\
\text { syncope varied from the } 2 \text { nd } \\
\text { day to the } 11 \text { th day of } \\
\text { hospitalization and } 2 \text { patients } \\
\text { had repeated syncope over a } 2 \text { - } \\
\text { min interval and suffered acute } \\
\text { traumatic brain injury as a } \\
\text { consequence; Cardiologic } \\
\text { investigation was normal in all } 4 \\
\text { patients and there was no } \\
\text { evidence of hypotension. }\end{array}$ & Reflex \\
\hline $\begin{array}{l}\text { Huang et al. } \\
\text { (U.S.A) }\end{array}$ & Case report & 1 & $\begin{array}{l}40 \text { year old } \\
\text { Female }\end{array}$ & Diabetes mellitus; Obesity & $\begin{array}{l}\text { Patient presented with fever \& } \\
\text { syncope and was admitted for } \\
\text { encephalitis; CSF was later } \\
\text { found to be positive for SARS- } \\
\text { COV-2 on rtPCR. }\end{array}$ & $\begin{array}{l}\text { Probable autonomic } \\
\text { dysfunction }\end{array}$ \\
\hline $\begin{array}{l}\text { Radmanesh } \\
\text { et al. } \\
\text { (U.S.A) }\end{array}$ & $\begin{array}{l}\text { Retrospective } \\
\text { study }\end{array}$ & $\begin{array}{l}242 \\
\text { ( } 79 \text { of whom } \\
\text { presented with } \\
\text { syncope) }\end{array}$ & $\begin{array}{l}\text { Mean age of } 68.7 \\
62 \% \text { male } \\
38 \% \text { female }\end{array}$ & - & $\begin{array}{l}242 \text { patients underwent at least } \\
1 \text { brain imaging (CT and/or } \\
\text { MRI) examination within } \\
2 \text { weeks of testing positive for } \\
\text { COVID-19; Syncope/fall was } \\
\text { one of the most common clinical } \\
\text { indications for imaging ( } 79 \\
\text { patients, } 32.6 \% \text { ); Of the } 13 \\
\text { patients with acute/subacute } \\
\text { infarcts, } 2 \text { were imaged due to } \\
\text { syncope/fall; Among the } 7 \\
\text { patients with acute hemorrhage, } \\
\text { the clinical indication was } \\
\text { syncope in } 4 \text { patients. }\end{array}$ & Unexplained \\
\hline $\begin{array}{l}\text { Chachkhiani } \\
\text { et al. } \\
\text { (U.S.A) }\end{array}$ & $\begin{array}{l}\text { Retrospective } \\
\text { study }\end{array}$ & $\begin{array}{l}250 \\
\text { ( } 6 \text { of whom had } \\
\text { syncope) }\end{array}$ & $\begin{array}{l}\text { Mean age of } 60 \\
45 \% \text { male } \\
80 \% \text { African American }\end{array}$ & $\begin{array}{l}\text { Group with Neurological } \\
\text { chief complaint: Arterial } \\
\text { Hypertension (71\%); } \\
\text { Diabetes mellitus (44\%). }\end{array}$ & $\begin{array}{l}34(14 \%) \text { patients had a } \\
\text { neurological chief complaint at } \\
\text { presentation, and syncope was } \\
\text { one of the most common }\end{array}$ & Unexplained \\
\hline
\end{tabular}


Table 3 (continued)

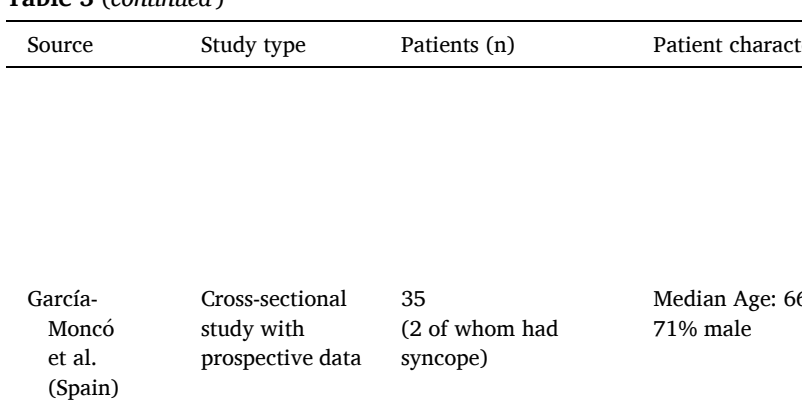

$\begin{array}{cll}\text { Xiong et al. } & \text { Retrospective } & 9 \\ \text { (China) } & \text { cohort study } & \text { (3 }\end{array}$

917

(3 of whom had syncope)

\section{Romero- \\ Sánchez \\ et al.}

(Spain)
Retrospective, observational study
841 syncope)
(5 of whom had
Mean age: 66.42 $56.2 \%$ male
Mean age: 48.7 $55 \%$ male
$44 \%$ had non-neurologic comorbidities $3 \%$ had neurologic comorbidities
Arterial Hypertension; Dyslipidemia; Obesity; Heart disease; Diabetes mellitus; Chronic kidney disease.
Median age: 63.0 $59.6 \%$ male

(48 of whom had syncope)
Arterial Hypertension (60\%); Diabetes mellitus (37\%).

Main findings $\quad$ Syncope type

complaints (2\%); Neurological complaints at presentation and during the hospital stay are associated with a higher risk of death,

prolonged hospital stay, and intubation.

Patients who presented with or developed a neurological disorder and were diagnosed with COVID-19 were analyzed. Of the 35 patients, 2 had syncope. CRP was elevated in most of the patients, especially in those who suffered from stroke. D-dimer was also frankly elevated, more so in the patients with stroke and in patients with encephalopathy. The CSF of one of these patients with syncope was tested for the presence of SARS-Cov-2 using the RT-PCR assay and was negative.

- Of the 917 people with COVID19, 39 had new-onset neurologic events (3 with syncope).

- The pts. with syncope were three women aged between 52 and 61 years without a previous history of neurologic or systemic disorders.ECGs recorded afterwards were normal. - Brain CT conducted in one of the syncope pts. did not reveal any new lesions. Of 841 patients hospitalized with COVID-19, 57.4\% developed some form of neurologic symptom. 5 patients suffered from a syncopal episode, all of which had nonsevere COVID-19 disease. Elevated CRP and D-dimer, with higher values in severe disease. In 21 patients (2.5\%), a neurologic manifestation was the reason that prompted the visit to the emergency department. 2 of those patients presented with syncope. Syncope was the presenting symptom in: $4 \%$ of patients in whom the highest level of care was the emergency department; $5.7 \%$ of pts. who needed hospital care; $3 \%$ of pts. who needed care in the intensive care unit. Elevated CRP and Ddimer.

A syncopal event occurred in $12 \%$ of patients with both neurological and typical COVID-19 symptoms (fever, cough and dyspnea) on presentation. Of the patients with neurological symptoms but without the typical COVID-19 symptoms, a syncopal event occurred in $4 \%$.

Patient 1: Complaints of presyncope with no other associated symptoms at the time of admission. Chest X Ray showed moderate cardiomegaly. The ECG
Unexplained

\section{Unexplained}

Unexplained

Unexplained

Unexplained cause

Presumable cardiac

$\begin{array}{ll}\text { Espinoza } & \text { Case series } \\ \text { et al. } & \text { (2 of whom } \\ \text { (U.S.A) } & \text { experienced } \\ & \text { presyncope) }\end{array}$

Patient 1: 80 year old female

Patient 2: 54 year old male

Patient 3: 64 year old female
Disease, Ischemic

Cardiomyopathy, 30\%

ejection fraction, Atrial

Fibrillation, Arterial

Hypertension and Type 2 
Table 3 (continued)

Source Study type Patients (n) Patient characteristics

Comorbidities

Main findings

Syncope type

Diabetes Mellitus; Patient 2:

Dyslipidemia; Patient 3:

Hypothyroidism

45 year old Hispanic

female

et al.

(U.S.A)
Case report $\quad 1$

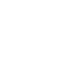

\section{Mizrahi et al.} (Israel)

Retrospective study and survey analysis

Khan et al.

(U.S.A)
Case report

PRIMARY CARE
VISITS
4066 COVID-19
positive adults ( 24 of
whom experienced
syncope)
862 COVID-19
positive children
( 3 of whom
experienced syncope)
SURVEY
RESPONDERS:
499 COVID-19
positive adults.

PRIMARY CARE

VISITS

Adults: Mean age:

43.03; 56\% male

Children: Mean age:

10.69; $51 \%$ male

SURVEY

RESPONDERS:

Adults: Mean age:

42.15; $46 \%$ male

1

Hyp

(a)


Table 3 (continued)

Source Study type

Patients (n)

Patient characteristics

Comorbidities

Main findings

Syncope type

Chalela et al. Case report (Spain)

Pérez et al.

(Spain)

Case report

1

Chibane et al. Case report (Canada)
78 year old male

63 year old male

Myotonic Dystrophy Disease (Steiner disease); Hiatal hernia.

Arterial Hypertension; Dyslipidemia;

Hyperuricemia; Chronic bronchitis; Pulmonary

fibrosis

ymptomatic Junctional Bradycardia and a permanent pacemaker implanted 6 years earlier; Immune thrombocytopenia; Breast cancer; Hodgkin's lymphoma; Splenectomy; Raynaud's phenomenon; Coronary Artery Disease. consistent with pulmonary embolism. In one hour, the patient developed acute respiratory distress syndrome and shock. Bedside transthoracic echocardiogram revealed a large right heart thrombus-in-transit through the tricuspid valve into the right ventricle. A limited transthoracic echocardiogram was performed 1 week later, which showed preserved RV systolic function and no evidence of thrombus. Patient presented a transient loss of consciousness and muscle strength with spontaneous recovery while walking in the street; Electrocardiography demonstrated sinus tachycardia and complete right bundle branch block; D-dimer was elevated. A CT pulmonary angiography was performed and detected an obstruction of the posterior-basal and anteriorbasal segmental arterial branches of the right lower lobe. Patient resorted to the emergency room for complaints of a syncopal episode without prodromes, abnormal body movements or automatisms. Recovery was observed in $2 \mathrm{~min}$. No other symptoms were mentioned. Laboratory data showed a decreased glomerular filtration rate and an elevated Ddimer. Chronic medication with ACE-i. An angio-CT was performed in order to exclude pulmonary embolism, which it did. Instead, it revealed parenchymal alveolar infiltrates in the upper left lobule. COVID19 test came back positive. Generalized malaise preceding pre-syncopal episode with no mention of infectious symptoms. Presence of mild livedo. Laboratory data showed elevated white blood cell count, creatinine and hs-troponin $\mathrm{T}$ levels. Initial COVID-19 rtPCR was negative. Transthoracic echocardiography showed very unusual hyperdense smoke-like haze in the right cardiac chambers and the inferior vena cava, suggesting pulmonary embolism. On day 2, the patient was found with aphasia and right-hand hemiparesis. Skin showed diffuse livedo racemosa, involving the whole body. Head CT documented loss of left frontal lobe gray-white matter differentiation, consistent with a hyperacute infarct. D-dimer was frankly elevated. Within minutes of starting heparin without bolus, there was hemodynamic collapse (mean arterial pressure of $60 \mathrm{mmHg}$ ).
Cardiopulmonary

Unexplained

Cardiopulmonary 
Table 3 (continued)

\begin{tabular}{cllll}
\hline Source & Study type & Patients (n) & Patient characteristics & Comorbidities \\
\hline & & & & \\
& & & \\
Martín- & Retrospective & 1379 & Mean age: 62 years old & Arterial Hypertension \\
Sánchez & observational & (68 of whom & $53.5 \%$ male & $(40.5 \%)$ D Dyslipidemia \\
et al. & study & experienced a & & $(37.9 \%)$ Diabetes mellitus \\
(Spain) & & syncopal event) & & $(9.2 \%)$.
\end{tabular}

\begin{tabular}{|c|c|c|c|c|}
\hline $\begin{array}{l}\text { Pendower } \\
\text { et al. } \\
\text { (United } \\
\text { Kingdom) }\end{array}$ & Case report & 1 & 64 year old female & $\begin{array}{l}\text { Asthma; Hypothyroidism; } \\
\text { Depression; Unprovoked } \\
\text { deep vein thrombosis } \\
10 \text { years earlier. }\end{array}$ \\
\hline
\end{tabular}

70 year old Hispanic female
Arterial Hypertension; Dyslipidemia; Diabetes mellitus; supraventricular tachycardia treated successfully with ablation.

Doodnauth $\quad$ Case report
et al.

Main findings

Post-mortem COVII

returned positive.

The population aged 65 and older showed a higher percentage of patients with a syncopal event $(p<0.001)$; $45-54$ years: $4.5 \%$ of patients experienced a syncopal event; 55-64 years: $2.8 \%$; $65-74$ years: 5.9\%; 75-84 years: $8.5 \%$; $\geq 85$ years: $9.8 \%$; In the $18-44$ age group, no patient exhibited signs of syncope.

2 episodes of syncope prompted a visit to the emergency department. The patient had felt generally unwell with some breathlessness for the preceding 2 weeks. Oxygen saturations were $96 \%$ on room air, but while in hospital acutely desaturated to $76 \%$. D-dimer, NT-proBNP and troponin T were elevated. CT pulmonary angiogram showed extensive bilateral lobar, segmental and subsegmental pulmonary emboli with a large saddle embolus, with dilatation of the right ventricle. Bedside echocardiogram confirmed right heart strain; Thrombolysis was conducted and the patient had a very good clinical response.

Witnessed syncopal episode upon standing following a week of progressive weakness, polyuria and hyperglycemia. On admission, blood pressure was 84/55 mmHg and oxygen saturation was $88 \%$ on room air. ECG showed the S1Q3T3 pattern, prolonged QTc and Twave inversions. D-dimer, PCR and pro-BNP were elevated. Bedside echocardiogram revealed a moderately dilated right ventricle without thrombus. CT pulmonary angiogram showed a saddle pulmonary embolism with notable thrombus in the right atrium extending into the right ventricle. Despite treatment, the patient did not survive.

Witnessed syncopal episode. Prior to the syncopal event, the patient complained of abdominal discomfort. Mildly elevated inflammatory markers. Chest X-ray revealed a small left-sided pleural effusion. rtPCR was positive for COVID19. ECG showed sinus bradycardia. On day 3 the patient developed renal failure and hypoxemia. An electrophysiology study revealed a delayed sinus node recovery time, confirming sinus node dysfunction.

Patients were stratified according to the presence of respiratory and/or neurologic

disturbances at admittance in
Syncope type

Unexplained

Cardiopulmonary

Cardiopulmonary

Presumable cardiac cause
Median age of 64 years Arterial Hypertension

$51.7 \%$ male

$81.7 \%$ caucasian
(44\%); Obesity (24.4\%);

Diabetes mellitus (19.5\%);
(81 of whom
experienced syncope) 
Table 3 (continued)

\begin{tabular}{|c|c|c|c|c|c|c|}
\hline Source & Study type & Patients (n) & Patient characteristics & Comorbidities & Main findings & Syncope type \\
\hline & & & & $\begin{array}{l}\text { Ischemic Heart Disease } \\
(12.2 \%) .\end{array}$ & $\begin{array}{l}\text { the Emergency Department. } \\
\text { Patients underwent cerebral CT } \\
\text { scan in case of stroke, seizure or } \\
\text { syncope. The majority } \\
\text { presented only respiratory } \\
\text { symptoms ( } 69.8 \% \text { ) while } 30.2 \% \\
\text { displayed at least one } \\
\text { neurological complaint. The } \\
\text { most common neurological } \\
\text { complaints were dysgeusia/ } \\
\text { anosmia ( } 9.1 \% \text { ) and syncope } \\
\text { (9\%). The presence of any } \\
\text { neurologic involvement was } \\
\text { higher in patients with } \\
\text { moderate disease when } \\
\text { compared to those with critical } \\
\text { or severe disease. However, no } \\
\text { significant difference was found } \\
\text { when it came to the occurrence } \\
\text { of syncope (10.1\% versus } 7.6 \% \text {, } \\
p=0.193 \text { ). }\end{array}$ & \\
\hline $\begin{array}{l}\text { Gonfiotti } \\
\text { et al. } \\
\text { (Italy) }\end{array}$ & Case series & $\begin{array}{l}5 \\
\text { ( } 2 \text { of whom } \\
\text { experienced syncope) }\end{array}$ & $\begin{array}{l}\text { Patient 1: } 67 \text { year old } \\
\text { male } \\
\text { Patient 2: } 74 \text { year old } \\
\text { male } \\
\text { Patient 3: } 70 \text { year old } \\
\text { male } \\
\text { Patient 4: } 80 \text { year old } \\
\text { male } \\
\text { Patient 5: } 79 \text { year old } \\
\text { male }\end{array}$ & $\begin{array}{l}\text { Patient 1: Rheumatoid } \\
\text { Arthritis and squamous } \\
\text { laryngeal tumour. Patient 2: } \\
\text { Chronic Obstructive } \\
\text { Pulmonary Disease. Patient } \\
\text { 3: Chronic Obstructive } \\
\text { Pulmonary Disease, } \\
\text { hypothyroidism, Lung } \\
\text { cancer. Patient 4: Chronic } \\
\text { Obstructive Pulmonary } \\
\text { Disease, Arterial } \\
\text { Hypertension and Peripheral } \\
\text { Arterial Occlusive Disease, } \\
\text { Lung cancer }\end{array}$ & $\begin{array}{l}\text { Patient 3: } 10 \text { days after the } \\
\text { patient underwent surgery for } \\
\text { an adenocarcinoma of the right } \\
\text { upper lung lobe, fever, cough, } \\
\text { diarrhea, syncope/hypotension } \\
\text { and anemia without bleeding } \\
\text { occured. PCR for COVID-19 was } \\
\text { positive. On day 25, the patient } \\
\text { exhibited acute renal failure. He } \\
\text { was on the Intensive Care Unit } \\
\text { for } 25 \text { days, underwent } \\
\text { mechanical ventilation for } 22 \\
\text { and died on day } 32 \text {. Patient } 4: \\
16 \text { days after the patient } \\
\text { underwent robotic-assisted } \\
\text { middle lobectomy, a sudden } \\
\text { episode of marked hypotension/ } \\
\text { syncope (blood pressure } 85 / \\
50 \text { mmHg) and tachycardia was } \\
\text { observed. Anemia and an } \\
\text { elevated white blood count } \\
\text { were also present. The patient } \\
\text { had no respiratory symptoms. } \\
\text { His COVID-19 test came back } \\
\text { positive. He was discharged on } \\
\text { day } 30 \text {. }\end{array}$ & Unexplained \\
\hline $\begin{array}{l}\text { Lam et al. } \\
\text { (Australia) }\end{array}$ & Letter & $\begin{array}{l}18 \\
\text { (1 with presyncope) }\end{array}$ & $\begin{array}{l}\text { Mean age: } 59 \text { years } \\
61 \% \text { male }\end{array}$ & $\begin{array}{l}\text { Obesity; Ischemic heart } \\
\text { disease; Diabetes mellitus; } \\
\text { Arterial Hypertension. }\end{array}$ & $\begin{array}{l}5 \% \text { of patients exhibited } \\
\text { presyncope }\end{array}$ & Unexplained \\
\hline $\begin{array}{l}\text { Kanjwal et al. } \\
\text { (U.S.A) }\end{array}$ & Case report & 1 & 36 year old female & No previous medical history. & $\begin{array}{l}\text { Patient experienced only mild } \\
\text { symptoms during her SARS- } \\
\text { COV-2 infection. Three to four } \\
\text { weeks after the COVID-19 } \\
\text { diagnosis, the patient } \\
\text { experienced fatigue, headaches, } \\
\text { dizziness, chest pain, } \\
\text { palpitations and presyncope. } \\
\text { ECG, stress test and a } \\
\text { transthoracic echocardiogram } \\
\text { were normal. She had a sitting } \\
\text { heart rate of } 86 \text { bpm and blood } \\
\text { pressure of } 115 / 65 \text { mmHg. } \\
\text { Upon standing, heart rate } \\
\text { increased to } 115 \text { bpm and blood } \\
\text { pressure } 105 / 70 \text { mmHg. } \\
\text { Findings of Tilt Test were } \\
\text { suggestive of POTS. }\end{array}$ & $\begin{array}{l}\text { Autonomic } \\
\text { dysfunction } \\
\text { (POTS) }\end{array}$ \\
\hline $\begin{array}{l}\text { Miglis et al. } \\
\text { (U.S.A) }\end{array}$ & Case report & 1 & 26 year old female & $\begin{array}{l}\text { Exercise-induced asthma; } \\
\text { obsessive compulsive } \\
\text { disorder resolved at age } 18 \text {. }\end{array}$ & $\begin{array}{l}3 \text { weeks after the patient's } \\
\text { COVID-19 diagnosis, she } \\
\text { developed orthosthatic } \\
\text { lightheadedness and } \\
\text { presyncope; On day } 24 \text {, episodic } \\
\text { sensations of "adrenaline } \\
\text { surges" began. On day } 45 \text {, } \\
\text { episodic facial fushing, }\end{array}$ & $\begin{array}{l}\text { Autonomic } \\
\text { dysfunction } \\
\text { (Hyperadrenergic } \\
\text { POTS) }\end{array}$ \\
\hline
\end{tabular}


Table 3 (continued)

\begin{tabular}{|c|c|c|c|c|c|c|}
\hline Source & Study type & Patients (n) & Patient characteristics & Comorbidities & Main findings & Syncope type \\
\hline Chou et al. & $\begin{array}{l}\text { Retrospective } \\
\text { and prospective } \\
\text { cohort study }\end{array}$ & $\begin{array}{l}3055 \\
\text { (152 with syncope) }\end{array}$ & $\begin{array}{l}\text { Mean age: } 59.9 \text { years } \\
57 \% \text { male overall } \\
63 \% \text { male in the } \\
\text { syncope cohort }\end{array}$ & $\begin{array}{l}\text { Preexisting neurological } \\
\text { disorders; diabetes; coronary } \\
\text { artery disease; hypertension; } \\
\text { cerebrovascular disease }\end{array}$ & $\begin{array}{l}\text { dermatographia, and non- } \\
\text { pruritic hives. } 3 \text { months after } \\
\text { symptom onset, the patient } \\
\text { underwent autonomic reflex } \\
\text { testing. Exaggerated postural } \\
\text { tachycardia with a heart rate } \\
\text { increase of } 65 \text { bpm on Head-Up- } \\
\text { Tilt test. Episodic hypertensive } \\
\text { systolic BP surges to } 170 \text { mmHg } \\
\text { in an oscillatory pattern. Robust } \\
\text { blood pressure responses to } \\
\text { Valsalva maneuver pattern in } \\
\text { the absence of hyperventilation, } \\
\text { suggestive of a hyperadrenergic } \\
\text { state. } \\
\text { Syncope was the least common } \\
\text { symptom, with an incidence of } \\
152 \text { of } 3054 \text { (5\%) in the all } \\
\text { COVID-19 cohort. } \\
8 \% \text { of the }>80 \text { age group } \\
\text { suffered from an episode of } \\
\text { syncope, being the age group } \\
\text { with the biggest incidence of } \\
\text { syncope. } \\
5 \% \text { of the patients who had an } \\
\text { episode of syncope died, } \\
\text { whereas in the non-syncope } \\
\text { group, } 14 \% \text { of patients died. }\end{array}$ & Unexplained \\
\hline
\end{tabular}

syncope playing a role not only during the acute phase of the disease, but also as a long-term consequence. In both these cases, the patients were diagnosed with a Postural Orthostatic Tachycardia Syndrome, included in the autonomic dysfunctions.

As stated before, unexplained pre/syncope was the most common cause of the transient loss of consciousness, being $87.9 \%(531 / 604)$ of the reported episodes. The overall frequency of reflex pre/syncope was $7.8 \%(47 / 604)$. Orthostatic hypotension accounted for $2.2 \%(13 / 604)$ and presumable cardiac pre/syncope was responsible for $2.2 \%(13 / 604)$ of the cases as well.

Regarding the comorbidities of patients with COVID-19 and syncope, arterial hypertension was heavily represented in 21 studies (Oates et al., 2020, Ebrille et al., 2020, Romero-Sánchez et al., 2020, Tapé et al., 2013, Sang et al., 2020, Singhania et al., 2020, Pérez et al., 2020, Aoi et al., 2020, Doodnauth et al., 2021, Chachkhiani et al., 2020, Canetta et al., 2020, Chuang et al., 2021, Mizrahi et al., 2020, Martín-Sánchez et al., 2020, Travi et al., 2020, Birlutiu et al., 2020, Argenziano et al., 2020, Espinoza et al., 2021, Gonfiotti et al., 2020, García-Moncó et al., 2020, Lam et al., 2020), making it the most prevalent comorbid condition exhibited by the participants. This was followed by Diabetes mellitus, obesity, dyslipidemia and heart disease. As shown in Table 6, detailed data concerning comorbidities were possible to evaluate for $102 \mathrm{pa}$ tients, and data concerning drug usage were then obtained for the 53 hypertensive patients. Arterial hypertension was present in $52.0 \%$ of patients and either ARBs or ACEi were used by $60.4 \%$ of hypertensive patients with COVID-19 and syncope.

Out of the 18 case reports, syncope was the reason that prompted the visit to the Emergency Department in 13 of them (72.2\%) (Tapé et al., 2013, Pasquetto et al., 2020, Luetkens et al., 2020, Logmin et al., 2020, Chang et al., 2020, Singhania et al., 2020, Huang et al., 2020, Chalela et al., 2020, Pérez et al., 2020, Chibane et al., 2020, Pendower et al., 2020, Aoi et al., 2020, Doodnauth et al., 2021). Furthermore, Ebrille et al. (2020), Canetta et al. (2020) and Espinoza et al. (2021) also described syncope as the presenting symptom of the infection. From these studies, we calculated that, on average, syncope occurred $3.16 \pm 1.40$ days before a positive COVID-19 test.

On the other hand, Argenziano et al. (2020) stated that syncope was the presenting symptom in only $4 \%$ of patients in whom the highest level of care was the emergency department, $5.7 \%$ of patients who required hospital care and $3 \%$ of patients who needed care in the ICU. In the retrospective study by Martín-Sánchez et al. (2020), no signs of syncope were exhibited by the $18-44$ age group, while in the $>85$ age group, syncope was observed in approximately $10 \%$ of the patients. Similarly, in Chou et al. (2021), the highest percentage of syncope patients was also observed in the $>80$ age group ( $8 \%$ ).

Considering confirmed or presumable cardiac syncope, the 13 reported cases included myocarditis (Luetkens et al., 2020), pulmonary embolisms (Khan et al., 2020, Chalela et al., 2020, Chibane et al., 2020, Pendower et al., 2020, Aoi et al., 2020) and ventricular fibrillation (Sang et al., 2020), Brugada Syndrome (Chang et al., 2020, Pasquetto et al., 2020), new onset atrial fibrillation together with anterior wall ST elevation myocardial infarction (Oates et al., 2020), sinus node dysfunction (Doodnauth et al., 2021), non-sustained tachycardia (Espinoza et al., 2021) and sinus bradycardia (Espinoza et al., 2021) as the underlying conditions.

The most common laboratory findings in COVID-19 patients presenting with syncope included elevated C-reactive protein, elevated Ddimer and elevated troponin. However, the elevation of C-reactive protein and D-dimer was more frequently observed than the elevation of troponin. From the studies that discriminated laboratory data on admission, we found that the elevation of D-dimer and C-reactive protein was present in $32 \%$ of the patients that presented with COVID-19 and syncope (Sang et al., 2020, Luetkens et al., 2020, Logmin et al., 2020, Khan et al., 2020, Chalela et al., 2020, Pérez et al., 2020, Chibane et al., 2020, Pendower et al., 2020, Aoi et al., 2020, Birlutiu et al., 2020, Espinoza et al., 2021). On the other hand, the elevation of troponin was observed in $23 \%$ of these patients (Pasquetto et al., 2020, Luetkens et al., 2020, Birlutiu et al., 2020, Espinoza et al., 2021). Troponin T was the most prevalent subtype studied among COVID-19 patients with syncope (Luetkens et al., 2020, Chibane et al., 2020, Pendower et al., 2020). Lymphocytopenia was also characteristic.

Data concerning the occurrence of syncope in patients either using or not using ACEi and/or ARBs, as well as beta blockers, were available for three studies (Oates et al., 2020, Canetta et al., 2020, Martín-Sánchez et al., 2020). There was a significant increase in episodes of syncope in patients under beta blocker treatment (39/236 cases versus 101/1231 
Table 4

Articles excluded with reasons.

\begin{tabular}{|c|c|}
\hline Source & Reason for exclusion \\
\hline $\begin{array}{l}\text { Sapp et al. } \\
\text { https://pubmed.ncbi.nlm.nih.gov/3 } \\
2299753 /\end{array}$ & $\begin{array}{l}\text { Did not describe cases of pre/syncope } \\
\text { as a symptom of the SARS-CoV-2 } \\
\text { infection. }\end{array}$ \\
\hline $\begin{array}{l}\text { Pasqualetto et al. } \\
\text { https://pubmed.ncbi.nlm.nih.gov/3 } \\
\text { 2665941/ }\end{array}$ & $\begin{array}{l}\text { The patient did not present with } \\
\text { syncope. }\end{array}$ \\
\hline $\begin{array}{l}\text { Babapoor-Farrokhran et al. } \\
\text { https://pubmed.ncbi.nlm.nih.gov/3 } \\
\text { 2989427/ }\end{array}$ & $\begin{array}{l}\text { The patient did not present with } \\
\text { syncope. }\end{array}$ \\
\hline $\begin{array}{l}\text { Bogaert et al. } \\
\text { https://pubmed.ncbi.nlm.nih.gov/ } \\
\text { 32933917/ }\end{array}$ & $\begin{array}{l}\text { The patient did not test positive for } \\
\text { COVID-19. }\end{array}$ \\
\hline $\begin{array}{l}\text { Favas et al. } \\
\text { https://pubmed.ncbi.nlm.nih.gov/ } \\
33089477 /\end{array}$ & Different study design. \\
\hline $\begin{array}{l}\text { Mahajan et al. } \\
\text { https://pubmed.ncbi.nlm.nih. } \\
\text { gov/32701540/ }\end{array}$ & $\begin{array}{l}\text { Did not describe cases of pre/syncope } \\
\text { as a symptom of the SARS-CoV-2 } \\
\text { infection. }\end{array}$ \\
\hline $\begin{array}{l}\text { Russo et al. } \\
\text { https://pubmed.ncbi.nlm.nih. } \\
\text { gov/33090884/ }\end{array}$ & $\begin{array}{l}\text { Did not describe cases of pre/syncope } \\
\text { in patients with COVID-19. }\end{array}$ \\
\hline $\begin{array}{l}\text { Filippo Crea } \\
\text { https://pubmed.ncbi.nlm.nih.gov/ } \\
\text { 33532851/ }\end{array}$ & $\begin{array}{l}\text { Did not describe cases of pre/syncope } \\
\text { in patients with COVID-19. }\end{array}$ \\
\hline $\begin{array}{l}\text { Nissan et al. } \\
\text { https://pubmed.ncbi.nlm.nih. } \\
\text { gov/33236588/ }\end{array}$ & $\begin{array}{l}\text { The episode of pre-syncope } \\
\text { experienced by the patient occured } \\
\text { during the year prior to the patient's } \\
\text { SARS-CoV- } 2 \text { infection. }\end{array}$ \\
\hline $\begin{array}{l}\text { Santacroce et al. } \\
\text { https://pubmed.ncbi.nlm.nih. } \\
\text { gov/33269412/ }\end{array}$ & $\begin{array}{l}\text { Did not describe cases of pre/syncope } \\
\text { in patients with COVID-19. }\end{array}$ \\
\hline $\begin{array}{l}\text { Alkeridy et al. } \\
\text { https://pubmed.ncbi.nlm.nih. } \\
\text { gov/32383778/ }\end{array}$ & $\begin{array}{l}\text { Although the patient suffered from a } \\
\text { fall, it was never stated that it had a } \\
\text { syncopal origin. }\end{array}$ \\
\hline $\begin{array}{l}\text { Townsend et al. } \\
\text { https://pubmed.ncbi.nlm.nih. } \\
\text { gov/33630906/ }\end{array}$ & Syncope was not addressed. \\
\hline $\begin{array}{l}\text { Gur et al. } \\
\text { https://dergipark.org. } \\
\text { tr/en/download/article-file/1173885 }\end{array}$ & $\begin{array}{l}\text { The syncope experienced in this } \\
\text { context was attributed to carbon } \\
\text { monoxide poisoning. }\end{array}$ \\
\hline $\begin{array}{l}\text { Hussain et al. } \\
\text { https://pubmed.ncbi.nlm.nih. } \\
\text { gov/32531128/ }\end{array}$ & $\begin{array}{l}\text { The syncope experienced by one } \\
\text { patient in this case-series was likely } \\
\text { associated with the patient's severe } \\
\text { aortic stenosis. }\end{array}$ \\
\hline $\begin{array}{l}\text { Motiejunaite et al. } \\
\text { https://pubmed.ncbinlm.nih. } \\
\text { gov/33536937/ }\end{array}$ & $\begin{array}{l}\text { The } 2 \text { cases of syncope during } \\
\text { exertion in COVID-19 survivors were } \\
\text { attributed to hypocapnic } \\
\text { hyperventilation, which is one of the } \\
\text { conditions that is commonly } \\
\text { misdiagnosed as syncope. }\end{array}$ \\
\hline
\end{tabular}

control cases; chi-square test $12.48, \mathrm{p}<0.01)$. However, this was not the case with ACEi and/or ARBs use (52/512 cases versus 88/1047 control cases, chi-square test $1.07, \mathrm{p}=0.30$ ).

Data concerning mortality were available for two studies (Oates et al., 2020, Chou et al., 2021) and statistical analysis showed mortality to be significantly less common in patients with syncope, when compared with those without this symptom (12/188 cases versus 419/ 2938 control cases, chi-square test 7.45, $\mathrm{p}<0.01)$.

\section{Discussion}

In the present report, the association of syncope with COVID-19 was under review. The results of our review suggest that syncope is a relatively uncommon manifestation of COVID-19, with an overall frequency of $4.2 \%$ in the reports under analysis. Different types of mechanisms leading to syncope in COVID-19 patients were observed, including reflex syncope, orthostatic hypotension and cardiac syncope. No single mechanism was identified that could explain all cases of this finding in the context under study.
Table 5

Demographic data of 5 of the included studies.

\begin{tabular}{lll}
\hline Source & Syncope cohort & Non-syncope cohort \\
\hline Oates et al. & - Number of patients: 37 & - Number of patients: 40 \\
(U.S.A) & - Mean age: 69 & - Mean age: 68 \\
& - Sex: 19 males $(51 \%)$ & - Sex: 23 males $(58 \%)$ \\
& - Beta blockers: $14(38 \%)$ & - Beta blockers: $9(22 \%)$ \\
& - ACE-I/ARBS: $15(41 \%)$ & - ACE-I/ARBS: $13(33 \%)$ \\
& - Number of deaths: 5 & - Number of deaths: $9(23 \%)$ \\
& (14\%) & \\
Chen et al. & - Number of patients: 24 & - Number of patients: 78 \\
(U.S.A) & - Mean age: 61 & - Mean age: 57 \\
Canetta et al. & - Number of patients: 35 & - Number of patients: 68 \\
(Italy) & - Mean age: 74 & - Mean age: 72 \\
& - Sex: 24 males $(69 \%)$ & - Sex: 51 males $(75 \%)$ \\
& - Beta Blockers: $11(31 \%)$ & - Beta Blockers: $18(26 \%)$ \\
Martín-Sanchez & - ACE-I/ARBS: $14(40 \%)$ & - ACE-I/ARBS: $30(44 \%)$ \\
et al. & - Number of patients: 68 & - Number of patients: 1311 \\
(Spain) & - Beta blockers: $14(21 \%)$ & - Beta blockers: $54(4 \%)$ \\
Chou et al. & - ACE-I/ARBS: $23(34 \%)$ & - ACE-I/ARBS: $45(3 \%)$ \\
& - Number of patients: 152 & - Number of patients: 2902 \\
& - Number of deaths: $7(5 \%)$ & - Number of deaths: 410 \\
& & (14\%) \\
\hline
\end{tabular}

Table 6

Associated clinical conditions described in 102 patients with COVID-19 and syncope and drug usage in 53 hypertensive patients with COVID-19 and syncope.

\begin{tabular}{lll}
\hline $\begin{array}{l}\text { Associated } \\
\text { conditions }\end{array}$ & Medications & $\mathrm{N}(\%)$ \\
\hline Arterial & & $52.0 \%(53 /$ \\
hypertension & & $102)$ \\
& Angiotensin receptor blockers OR angiotensin & $60.4 \%(32 /$ \\
& converting enzyme inhibitors & $53)$ \\
& Diuretics & - \\
& Beta blockers & $49.1 \%(26 /$ \\
& & $53)$ \\
& Calcium channel blockers & $22.6 \%(12 /$ \\
Diabetes mellitus & & $53)$ \\
& & $19.6 \%$ \\
Obesity & & $(20 / 102)$ \\
& & $15.7 \%(16 /$ \\
Coronary heart & & $102)$ \\
disease & & $14.7 \%(15 /$ \\
Renal & & $102)$ \\
insufficiency & & $12.7 \%$ \\
Dyslipidemia & $(13 / 102)$ \\
Atrial fibrillation & $9.8 \%(10 /$ \\
& $102)$ \\
\hline
\end{tabular}

Syncope may be the presenting symptom of COVID-19. Out of 18 case reports reviewed, syncope was the reason that prompted a visit to the Emergency Department in $72.2 \%$ of patients. This loss of consciousness occurred on average $3.16 \pm 1.40$ days before a positive COVID-19 test, which suggests that if syncope could be seen as a warning sign of a possible SARS-CoV-2 infection, this timely association could, in some cases, offer an opportunity to mitigate the dissemination of the disease by means of an early diagnosis.

Regarding the age of the patients, in the report by Martín Sánchez et al. (Martín-Sánchez et al., 2020), syncope showed a higher frequency in the $>85$ years age group (approximately $10 \%$ ) and was not present at all within the $18-44$ years old population. Data in the same direction were presented by Chou et al. (2021). Most of the reports included in our review included patients with a mean age of 60 years of age or older, with a few exceptions lying in the 40-60 age group (Table 3). This suggests that syncope, as a symptom of COVID-19, is more frequent in an elderly population. Because this population is particularly vulnerable to this novel virus, special attention should be paid. 
Considering the post-acute COVID-19 scenario, two recurring presyncopal episodes were described, and these happened in 26 and 36 year olds (Kanjwal et al., 2020, Miglis et al., 2020), which offers a great contrast to the age of people who suffered from syncope during the active infection. Long-term COVID-19 sequelae are still in need of further investigation in order to grasp the future impact that the infection might have on its survivors, especially after a longer period of time.

Arterial hypertension was present in more than half of the patients with COVID-19 and syncope for whom detailed data were available (Table 6). We did not find a significant association between the use of either ACEi or ARBs and the occurrence of syncope. Concerning the use of beta blockers, a significant difference was observed, with syncope being more frequent in patients taking this type of drugs. This may indicate that an adequate compensatory response of the heart rate is important in this inflammatory setting. The present results suggest a careful reevaluation of blood pressure whenever a hypertensive patient develops COVID-19, especially if beta-blockers are used.

The presence of lower heart rate and lower blood pressure at admission that was observed in patients presenting with syncope did not necessarily correlate with severe COVID-19, as it was noted that these patients required less intensive care than the non-syncope cohort (Oates et al., 2020).

Patients with self reported syncope had lower in-hospital mortality than those without this symptom, in the report by Chou et al. (2021) (and also in our results). This may not represent the situation concerning the whole universe of COVID-19 patients, but may be due to the fact that patients with alternative and serious neurological conditions were represented heavily in the control group. One may speculate that syncope was drug-associated in some cases, and that therefore, by having a reversible nature, may also contribute to this finding.

Different authors suggested several types of dysfunction of the cardiovascular system, of the neurological system, or of both, in the context under evaluation. ACE2 is believed to be involved in the regulation of cardiovascular function at the central nervous system level (Xia and Lazartigues, 2010). Perhaps the affinity of SARS-Cov-2 to the ACE-2 receptors could play a role in affecting the baroreflex response (Canetta et al., 2020). Following this reasoning, the inappropriate baroreflex response could lead to a partial inhibition of the compensatory increase of heart rate during fever and acute hypoxemia. An inadequate response of heart rate was suggested in some cases (Ebrille et al., 2020, Canetta et al., 2020), a situation perhaps worsened in the context of beta-blocker use.

In the present review, elevated D-dimers were one of the most frequent abnormal laboratory findings (32\%), supporting the concept that blood hypercoagulability, which is common among COVID-19 patients, is also present in patients who experience syncope while infected with SARS-CoV-2. A rise in troponins was also noted across some studies, underlining the impact of the virus in provoking a cardio-inflammatory response (Gaze, 2020).

\subsection{Limitations of this systematic review}

The large majority of studies in the present review are case reports, hence, the limitations include those intrinsic to this kind of studies, including the inability to generalize the results, mainly due to the fact that these studies do not show a representative population. In addition, case reports and case series have a retrospective nature, which means they sometimes lack relevant information. For example, some case reports did not mention the chronic medications the patients were on, although they described the respective comorbidities.

The population sample size is 14,437 which, when compared to the millions of COVID-19 cases worldwide, may be the subject of selection bias. We also analyzed a substantial amount of retrospective studies, most of which were not primarily designed to assess the frequency of syncope in the context of COVID-19 and therefore provide insufficient information regarding the syncope cohort. Given the nature of this topic, the number of published studies focusing on comparing syncope cohorts with non-syncope cohorts in a COVID-19 setting is still limited, hindering the ability to reach certain conclusions. We attempted at making a distinction between the different types of syncope, however, in some studies, we found it impossible to do so. Furthermore, our inclusion criteria limited the articles to those written in the English, Spanish, French, Italian and Portuguese languages, which may have omitted significant studies.

\section{Conclusions}

Syncope is a relatively uncommon manifestation of COVID-19, with an overall frequency of $4.2 \%$ in the reports under analysis. Different types of mechanisms leading to syncope in this context were observed, including reflex syncope, orthostatic hypotension and cardiac syncope. Syncope may be the presenting symptom of COVID-19 and its adequate recognition as such might be useful in allowing for an earlier diagnosis. The presence of this symptom does not necessarily correlate with severe COVID-19 and may be associated to lower in-hospital mortality. Arterial hypertension was particularly prevalent in patients with COVID-19 and syncope, which may indicate that maintaining the usual antihypertensive medication may be inadequate in some cases of COVID-19. This is particularly important in the case of beta-blockers use, drugs that were shown to be associated with an increased incidence of syncope. Further studies may be of interest in order to further evaluate the frequency, etiology and impact of syncope in this type of patients.

\section{References}

Aoi, S., Kakkar, A.M., Golowa, Y., Grushko, M., Coyle, C.M., Elrafei, T., et al., 2020. Saddle pulmonary embolism and clot in transit in COVID-19 infection: a case report of catastrophic venous thromboembolism. Eur. Heart J.

Argenziano, M.G., Bruce, S.L., Slater, C.L., Tiao, J.R., Baldwin, M.R., Barr, R.G., et al., 2020. Characterization and clinical course of 1000 patients with coronavirus disease 2019 in New York: retrospective case series. BMJ 369.

Birlutiu, V., Birlutiu, R.M., Feiereisz, A.I., 2020. SARS-CoV-2 infection associated with micturition syncope: our experience with 4 case reports. Medicine 99 (31).

Brignole, M., Moya, A., de Lange, F.J., Deharo, J.-C., Elliott, P.M., Fanciulli, A., et al., 2018. 2018 ESC guidelines for the diagnosis and management of syncope. Eur. Heart J. 39 (21), 1883-1948.

Canetta, C., Accordino, S., Buscarini, E., Benelli, G., La Piana, G., Scartabellati, A., et al., 2020. Syncope at SARS-CoV-2 onset. Auton. Neurosci. 229, 102734.

Cardiology ESo, 2018. ESC guidelines for the diagnosis and management of syncope. Eur. Heart J. https://doi.org/10.1093/eurheartj/ehy037.

Chachkhiani, D., Soliman, M.Y., Barua, D., Isakadze, M., Villemarette-Pittman, N.R., Devier, D.J., et al., 2020. Neurological complications in a predominantly African American sample of COVID-19 predict worse outcomes during hospitalization. Clin. Neurol. Neurosurg. 197, 106173.

Chalela, R., Caguana, O., Zuccarino, F., Khilzi, K., Rodríguez-Chiaradía, D.A., 2020. Case report on a patient with Steinert disease complicated by COVID-19. Vasc. Health Risk Manag. 16, 463.

Chang, D., Saleh, M., Garcia-Bengo, Y., Choi, E., Epstein, L., Willner, J., 2020. COVID-19 infection unmasking brugada syndrome. HeartRhythm Case Reports. 6 (5), 237-240.

Chen, T., Hanna, J., Walsh, E.E., Falsey, A.R., Laguio-Vila, M., Lesho, E., 2020. Syncope, near-syncope, or non-mechanical falls as a presenting feature of COVID-19. Ann. Emerg. Med.

Chibane, S., Gibeau, G., Poulin, F., Tessier, P., Goulet, M., Carrier, M., et al., 2020. Hyperacute multi-organ thromboembolic storm in COVID-19: a case report. J. Thromb. Thrombolysis 1-4.

Chou, S.H.-Y., Beghi, E., Helbok, R., Moro, E., Sampson, J., Altamirano, V., et al., 2021. Global prevalence of neurological manifestations among patients hospitalized with COVID-19: a report of the global consortium study of neurologic dysfunction in COVID-19 (GCS-NeuroCOVID) and the European Academy of Neurology [ENERGY]. In: Registry Collaborative.

Chuang, D.T., Aydemir, S., Magda, P., Thomas, C., Zarnegar, R., 2021. Neurological manifestations as primary presentation of COVID-19 in hospitalized patients. Acta Neurol. Scand.

Doodnauth, A.V., Jallad, A., Rizk, D., Valery, E., McFarlane, S.I., 2021. Syncope associated with sinus nodal dysfunction in a COVID-19 patient: a case report and review of the literature. Am. J. Med. Case Rep. 9 (4), 263.

Ebrille, E., Lucciola, M.T., Amellone, C., Ballocca, F., Orlando, F., Giammaria, M., 2020. Syncope as the presenting symptom of COVID-19 infection. In: HeartRhythm Case Reports.

Espinoza, D., Jasti, M., Malwi, U.H., Junia, C., 2021. Cardiovascular disease risk and outcomes in patients infected with SARS-CoV-2. Cureus. 13 (1). 
Favas, T., Dev, P., Chaurasia, R.N., Chakravarty, K., Mishra, R., Joshi, D., et al., 2020. Neurological manifestations of COVID-19: a systematic review and meta-analysis of proportions. Neurol. Sci. 1-34.

García-Moncó, J.C., Cabrera-Muras, A., Collía-Fernández, A., Erburu-Iriarte, M., RodrigoArmenteros, P., Oyarzun-Irazu, I., et al., 2020. Neurological reasons for consultation and hospitalization during the COVID-19 pandemic. Neurol. Sci. 41 (11), 3031-3038.

Gaze, D.C., 2020. Clinical utility of cardiac troponin measurement in COVID-19 infection. Ann. Clin. Biochem. 57 (3), 202-205.

Gonfiotti, A., Gatteschi, L., Salvicchi, A., Bongiolatti, S., Lavorini, F., Voltolini, L., 2020 Clinical courses and outcomes of five patients with primary lung cancer surgically treated while affected by severe acute respiratory syndrome coronavirus 2 . Eur. J. Cardiothorac. Surg. 58 (3), 598-604.

Huang, Y.H., Jiang, D., Huang, J.T., 2020. A case of COVID-19 encephalitis. Brain Behav. Immun.

Kanjwal, K., Jamal, S., Kichloo, A., Grubb, B.P., 2020. New-onset postural orthostatic tachycardia syndrome following coronavirus disease 2019 infection. J. Innov. Cardiac Rhythm Manag. 11 (11), 4302.

Khan, H.M.W., Khan, M.R., Munir, A., Moughrabieh, A., Changezi, H.U., 2020. A Giant right-heart thrombus-in-transit in a patient with COVID-19 pneumonia. Am. J. Case Rep. 21, e927380-e927381.

Lam, K., McClelland, S., Dallo, M.J., 2020. ECG: essential in care of patients with COVID19. Med. J. Aust. 213 (10)), $476 \mathrm{e} 1$.

Logmin, K., Karam, M., Schichel, T., Harmel, J., Wojtecki, L., 2020. Non-epileptic seizures in autonomic dysfunction as the initial symptom of COVID-19. J. Neurol. 1.

Luetkens, J.A., Isaak, A., Zimmer, S., Nattermann, J., Sprinkart, A.M., Boesecke, C., et al, 2020. Diffuse myocardial inflammation in COVID-19 associated myocarditis detected by multiparametric cardiac magnetic resonance imaging. Circ. Cardiovasc. Imaging 13 (5), e010897.

Martín-Sánchez, F.J., Del Toro, E., Cardassay, E., Carbó, A.V., Cuesta, F., Vigara, M., et al., 2020. Clinical presentation and outcome across age categories among patients with COVID-19 admitted to a Spanish emergency department. Euro. Geriatr. Med. 11 (5), 829-841.

Miglis, M.G., Prieto, T., Shaik, R., Muppidi, S., Sinn, D.-I., Jaradeh, S., 2020. A case report of postural tachycardia syndrome after COVID-19. Clin. Auton. Res. 30 (5), 449-451.

Mizrahi, B., Shilo, S., Rossman, H., Kalkstein, N., Marcus, K., Barer, Y., et al., 2020. Longitudinal symptom dynamics of COVID-19 infection. Nat. Commun. 11 (1), 1-10.

National Heart LaBI, 2021. Study Quality Assessment Tools. Available from: https ://www.nhlbi.nih.gov/health-topics/study-quality-assessment-tools.

Oates, C.P., Turagam, M.K., Musikantow, D., Chu, E., Shivamurthy, P., Lampert, J., et al. 2020. Syncope and presyncope in patients with COVID-19. Pacing Clin. Electrophysiol.

Omotosho, Y.B., Ying, G.W., Stolar, M., Mallari, A.J.P., 2021. COVID-19-induced diabetic ketoacidosis in an adult with latent autoimmune diabetes. Cureus. 13 (1).

Organization, 2021. WH. WHO Coronavirus (COVID-19) Dashboard [July 1, 2021]. Available from: https://covid19.who.int/.
Page, M.J., McKenzie, J.E., Bossuyt, P.M., Boutron, I., Hoffmann, T.C., Mulrow, C.D., et al., 2021. Updating guidance for reporting systematic reviews: development of the PRISMA 2020 statement. J. Clin. Epidemiol. 134, 103-112.

Pasquetto, G., Conti, G.B., Susana, A., Leone, L.A., Bertaglia, E., 2020. Syncope, Brugada syndrome, and COVID-19 lung disease. J. Arrhythmia 36 (4), 768-770.

Pendower, L., Benedetti, G., Breen, K., Karunanithy, N., 2020. Catheter-directed thrombolysis to treat acute pulmonary thrombosis in a patient with COVID-19 pneumonia. BMJ Case Rep. CP. 13 (8), e237046.

Pérez, I.H., de la Esperanza, B.T., Peñacoba, G.V., Azorin, D.G., 2020. Isolated syncope as a form of presentation of COVID-19 infection. Neurología (English Edition).

Radmanesh, A., Raz, E., Zan, E., Derman, A., Kaminetzky, M., 2020. Brain imaging use and findings in COVID-19: a single academic center experience in the epicenter of disease in the United States. Am. J. Neuroradiol. 41 (7), 1179-1183.

Romero-Sánchez, C.M., Díaz-Maroto, I., Fernández-Díaz, E., Sánchez-Larsen, Á., LayosRomero, A., García-García, J., et al., 2020. Neurologic manifestations in hospitalized patients with COVID-19: the ALBACOVID registry. Neurology.

Sang, C.J., Heindl, B., Von Mering, G., Rajapreyar, I., 2020. Massive pulmonary embolism in a COVID-19 patient: a case report. European Heart Journal-Case Reports.

Santacroce, L., Charitos, I.A., Carretta, D.M., De Nitto, E., Lovero, R., 2020. The human coronaviruses (HCoVs) and the molecular mechanisms of SARS-CoV-2 infection. J. Mol. Med. 1-14.

Shafi, A.M., Shaikh, S.A., Shirke, M.M., Iddawela, S., Harky, A., 2020. Cardiac manifestations in COVID-19 patients-a systematic review. J. Card. Surg. 35 (8), 1988-2008.

Singhania, N., Bansal, S., Singhania, G., 2020. An atypical presentation of novel coronavirus disease 2019 (COVID-19). Am. J. Med.

Tadic, M., Cuspidi, C., Grassi, G., Mancia, G., 2020. COVID-19 and arterial hypertension: hypothesis or evidence? J. Clin. Hypertens. 22 (7), 1120-1126.

Tapé, C., Byrd, K.M., Aung, S., Lonks, J.R., Flanigan, T.P., Rybak, N.R., 2013. COVID-19 in a patient presenting with syncope and a normal chest X-ray. Rhode Island Med. J. 103, 50, 2020.

Terpos, E., Ntanasis-Stathopoulos, I., Elalamy, I., Kastritis, E., Sergentanis, T.N., Politou, M., et al., 2020. Hematological findings and complications of COVID-19. Am. J. Hematol.

Travi, G., Rossotti, R., Merli, M., D’Amico, F., Chiappetta, S., Panariello, A., et al., 2020. Neurological Manifestations in Patients Hospitalized With COVID-19: A Retrospective Analysis From a Large Cohort in Northern Italy.

Wang, M.-Y., Zhao, R., Gao, L.-J., Gao, X.-F., Wang, D.-P., Cao, J.-M., 2020. SARS-CoV-2: structure, biology, and structure-based therapeutics development. Front. Cell. Infect. Microbiol. 10.

Xia, H., Lazartigues, E., 2010. Angiotensin-converting enzyme 2: central regulator for cardiovascular function. Curr. Hypertens. Rep. 12 (3), 170-175.

Xiong, W., Mu, J., Guo, J., Lu, L., Liu, D., Luo, J., et al., 2020. New onset neurologic events in people with COVID-19 in 3 regions in China. Neurology 95 (11), e1479-e1487. 